\title{
Dampak Work Related Stress Terhadap Kinerja Tenaga Pemasaran
}

\author{
Rizky Praditiya Herdiana*, Maya Setiawardhani \\ Jurusan Administrasi Niaga, Politknik Negeri Bandung
}

\begin{abstract}
:
Human resources is one important aspect to run the company activities. The company needs to manage their human resources to achieve optimal results. Managing employee's work stress may impact optimal employee performance. This study aim to find out the impact work related stress on employee performance account executive in PT Agrodana Futures Bandung. This research used deskriptive quantitative method. Based on research on 110 respondents, the results show that there is an impact from work related stress on employee performance. The regression analysis showing the results $Y=6,120+0,478 X$. This shows that if the work-related stress increases one, then it will add employee's performance equal to 0,478 and work related stress influnced $64,2 \%$ employee performance and the rest is influenced by other. Although the performance of account executive employees of PT Agrodana Futures Bandung is high, but the company can still improve their performance to the best.
\end{abstract}

Keywords: work related stress, employees performance, human resources.

\section{Pendahuluan}

Sumber daya manusia merupakan aspek penting di dalam sebuah perusahaan. Sumber daya manusia dibutuhkan oleh perusahaan untuk menyelesaikan tugas-tugas perusahaan. Sumber daya manusia berperan aktif di dalam kegiatan perusahaan, mereka yang menjadi pelaku, perencana, dan penentu terwujudnya tujuan suatu perusahaan. Sumber daya manusia yang berkinerja tinggi dibutuhkan untuk meningkatkan produktifitas perusahaan. Manajemen sebuah perusahaan dituntut untuk mempertahankan sumber daya manusianya pada kinerja yang tinggi dan mengembangkan setiap potensinya agar memberikan kontribusi yang optimal dan maksimal pada perusahaan.

Dalam mengerjakan sebuah tugas, timbulah tekanan-tekanan yang harus dihadapi oleh setiap individu. Karyawan yang merupakan penunjang untuk mencapai tujuan perusahaan, memiliki perasaan, keingingan, dan pikiran yang mempengaruhi sikap dalam melakukan pekerjaan. Sikap ini yang nantinya menentukan kinerja, kecintaan, dan dedikasinya terhadap pekerjaan yang diberikan perusahaan.

Salah satu sikap yang muncul pada karyawan dalam melaksanakan tugasnya yaitu stres kerja. Menurut Sunyoto (2013), stres kerja merupakan satu kondisi dimana karyawan berhadapan dengan sebuah peluang, tuntutan, dan sumber daya yang berhubungan dengan keingingan karyawan tersebut yang hasilnya tidak pasti dan penting. Stres kerja berpengaruh terhadap jalan pikiran, emosi, dan kondisi fisik karyawan. Kemampuan masing-masing karyawan menangani stres tidaklah selalu sama. Terdapat karyawan yang mempunyai daya tahan stres yang tinggi dan rendah. Stres yang tidak diatasi dengan baik dan dibiarkan berlarut-larut akan berakibat pada kondisi mental, emosional, dan ketidakmampuan berinteraksi dengan lingkungannya sehingga mempengaruhi kinerja karyawan tersebut. 
PT. Agrodana Futures merupakan perseroan berbadan hukum di Indonesia yang bergerak di bidang Perdagangan Berjangka. Didirikan pada tanggal 17 Mei 2000 di Jakarta. PT. Agrodana Futures memiliki izin dari Badan Pengawasan Perdagangan Berjangka Komoditi (BAPPEBTI) untuk melakukan kegiatan Perdagangan Berjangka sesuai dengan UU No. 32 tahun 1997 yang disempurnakan dengan UU No. 10 tahun 2011 dengan nomor izin 40/BAPPEBTI/SI/XII/2000.

PT. Agrodana Futures adalah perusahaan pialang berjangka di Indonesia, yang menjual produk Valuta Asing, Komoditas dan Indeks Saham Bursa Asia. Memiliki kantor pusat di Jakarta dan memiliki cabang di Bandung, Surabaya, dan Lampung. Setiap kantor cabang yang dimiliki oleh PT. Agrodana Futures merupakan marketing branch atau didirikan untuk kegiatan pemasarannya. Pada kantor marketing branch ini terdapat karyawan account executive yang lebih banyak dari pada karyawan di bagian lain yaitu berjumlah kisaran 150 orang pegawai.

Tabel 1 Pergantian Karyawan Account Executive PT. Agrodana Futures Bandung Tahun 2017

\begin{tabular}{|l|l|l|l|}
\hline \multicolumn{1}{|c|}{ Waktu } & $\begin{array}{c}\text { Karyawan yang keluar dan } \\
\text { dikeluarkan Account executive }\end{array}$ & $\begin{array}{c}\text { Total Karyawan } \\
\text { Account executive }\end{array}$ & $\begin{array}{c}\text { Persentase } \\
(\%)\end{array}$ \\
\hline $\begin{array}{l}\text { Triwulan } 1 \\
2017\end{array}$ & 100 & 150 & 66,6 \\
\hline $\begin{array}{l}\text { Triwulan } 2 \\
2017\end{array}$ & 98 & 150 & 65,3 \\
\hline $\begin{array}{l}\text { Triwulan } 3 \\
2017\end{array}$ & 100 & 150 & 66,7 \\
\hline $\begin{array}{l}\text { Triwulan } 4 \\
2017\end{array}$ & 101 & 150 & 64 \\
\hline
\end{tabular}

Sumber : Data olahan (2018)

Menurut tabel 1 jumlah karyawan yang masuk dan keluar karyawan pada PT. Agrodana Futures Bandung rata-rata dari triwulan 12017 - triwulan 42017 yaitu 99,75 karyawan. Jadi dapat diartikan bahwa terdapat 100 karyawan yang keluar pada setiap triwulan tahun 2017. Diindikasikan terdapat masalah pada pencapaian target yang dilakukan oleh karyawan account executive atau karyawan account executive tidak mencapai target dalam mendapatkan investor.

Tabel 2 Hasil Pra Peneltian

\begin{tabular}{|l|l|l|l|}
\hline No & Pertanyaan & Ya & Tidak \\
\hline 1 & $\begin{array}{l}\text { Ketidakpastian mengenai apa yang harus dikerjakan } \\
\text { membuat stres }\end{array}$ & $65 \%$ & $35 \%$ \\
\hline 2 & Pencapaian target yang tidak pasti menimbulkan stres & $70 \%$ & $30 \%$ \\
\hline 3 & $\begin{array}{l}\text { Bekerja dibawah tekanan waktu menyebabkan saya } \\
\text { merasa resah }\end{array}$ & $70 \%$ & $30 \%$ \\
\hline 4 & $\begin{array}{l}\text { Saya terlalu banyak mengerjakan pekerjaan di tempat } \\
\text { kerja }\end{array}$ & $60 \%$ & $40 \%$ \\
\hline 5 & $\begin{array}{l}\text { Saya bingung terhadap apa yang harus diprioritaskan } \\
\text { untuk dikerjakan di tempat kerja }\end{array}$ & $55 \%$ & $45 \%$ \\
\hline
\end{tabular}

Sumber : Data olahan (2018)

Berdasarkan survey pra penelitian yang dilakukan terhadap 20 responden paling banyak menyatakan bahwa pencapaian target yang tidak pasti menimbulkan stres yaitu sebanyak $70 \%$ dan bekerja dibawah tekanan waktu menimbulkan keresahan sebanyak $70 \%$. Sementara ketidak pastian mengenai apa yang harus dilakukan sebesar 65\% mengatakan setuju. Sebanyak $60 \%$ mengatakan terlalu banyak pekerjaan, dan 55\% mengatakan bingung terhadapa apa yang harus diprioritaskan terlebih dahulu dalam pekerjaannya. Berdasarkan pemaparan tersebut dapat disimpulkan bahwa terjadi stres kerja yang tinggi pada karyawan account executive. 
Setelah melakukan Praktik Kerja Lapangan pada tanggan 17 Juli 2017 - 18 Agustus 2017 dapat diketahui bahwa karyawan account executive dituntut dan diberikan target untuk mendapatkan orang yang mau menginvestasikan uangnya pada transaksi komoditi dan derivatif. Terkadang, target pencapaian yang ditentukan oleh pihak manajemen perusahaan akan memberikan dorongan bagi karyawan. Tetapi, banyak karyawan mengalami stres dari pekerjaannya tersebut, perlu diketahui bahwa karyawan account executive merupakan ujung tombak perusahaan dan memiliki target kerja yang nantinya dapat mempengaruhi kinerja karyawan menjadi lebih baik atau lebih buruk. Perlu diketahui, PT. Agrodana Futures Bandung Marketing Branch akan memberhentikan kontrak dengan karyawan account executive yang tidak mencapai targetnya dalam mencari investor dalam waktu tiga bulan, dan jika berhasil maka perusahaan akan memperpanjang kontrak dengan karyawan, sehingga karyawan account executive akan mendapatkan stres kerja yang beragam, karena apabila mereka tidak mencapai target maka akan dikeluarkan dari perusahaan. Dalam kegiatan kerjanya, account executive melakukan yang terbaik dalam mendapatkan investor. Tidak ada job description yang jelas dalam pekerjaan account executive. Persaingan dalam mencari investor antar karyawan account executive pada PT. Agrodana Futures Bandung sangat tinggi, dikarenakan mereka sama-sama mencari investor agar dapat memperpanjang kontraknya dengan perusahan. Belum lagi mereka bersaing dengan karyawan account executive pada perusahaan broker lain. Hal-hal ini dapat menimbulkan stres kerja pada karyawan account executive, dimana menurut Robbins (2008) terdapat pemicu stres kerja, salah satunya dari faktor perusahaan yang mencakup:

1. Tuntutan tugas, yaitu faktor yang terkait dengan desain pekerjaan, kondisi kerja, dan lain-lain.

2. Tuntutan peran, yaitu beban berlebihan yang dialami ketika menjalankan peran dengan waktu yang tersedia.

3. Tuntutan antar pribadi, merupakan tekanan yang didapatkan dari karyawan lainnya, tidak mendapat dukungan dari teman, juga hubungan yang buruk dengan karyawan lain.

Stres kerja yang didapat oleh account executive bisa menambah kinerja karyawannya atau malah mengurangi kinerjanya. Untuk dapat meningkatkan dan mempertahankan kinerja yang baik pada pegawai account executive, maka diperlukan manajemen yang sesuai dalam mengatur stres kerja karyawannya sehingga dapat mencapai target. Berikut ini adalah grafik keterlambatan karyawan account executive PT. Agrodana Futures Bandung.

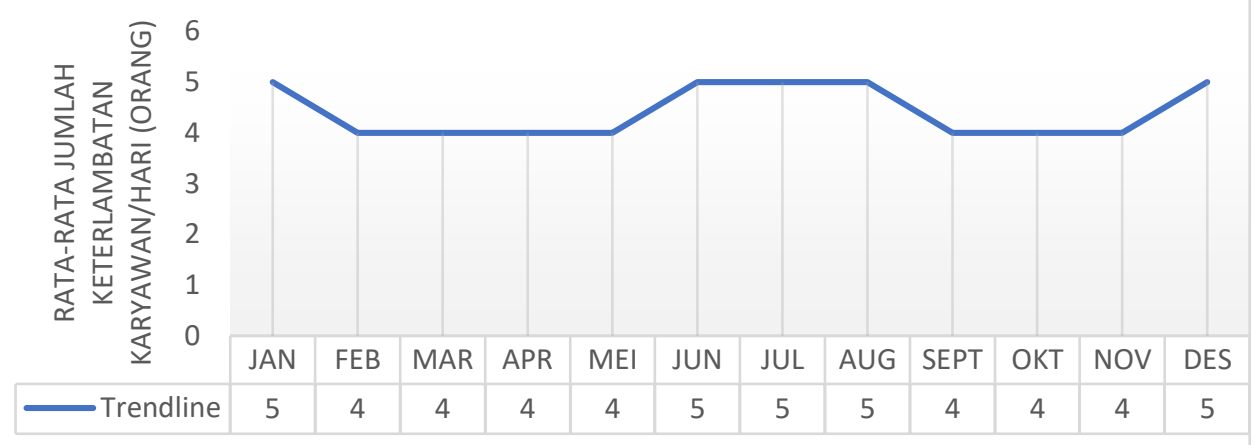

\section{Gambar 1 Tren Keterlambatan Karyawan Setiap Bulan Pada Tahun 2017}

Berdasarkan gambar 1 dengan stres kerja yang diindikasikan tinggi tetapi berdampak baik pada kehadiran karyawan account executive. Ini mengindikasikan dengan stres kerja yang tinggi bisa saja berpengaruh positif terhadap kinerja karyawan dalam dimensi yang lain. Berdasarkan uraian di atas, penelitian ini dibuat untuk membantu PT. Agrodana Futures Bandung (Marketing Branch) untuk agar memiliki gambaran mengenai kondisi yang dimiliki oleh karyawan account executivenya. Sesuai dengan latar belakang yang telah dijelaskan, tujuan penelitian yang dilakukan adalah:

1. Bagaimana stres kerja yang terjadi pada karyawan account executive PT. Agrodana Futures Bandung (Marketing Branch). 
2. Bagaimana kinerja karyawan account executive PT. Agrodana Futures Bandung (Marketing Branch).

3. Bagaimana dampak stres kerja terhadap kinerja karyawan account executive PT. Agrodana Futures Bandung (Marketing Branch).

\section{Kajian Literatur \\ Work related stress}

Stres kerja dapat dialami dan dirasakan oleh setiap manusia. Stres kerja dapat berdampak merugikan maupun menguntungkan/mendorong kinerja, bagi individu yang mengalaminya. Sunyoto (2013:42) mengemukakan bahwa "stres kerja adalah kondisi dinamis di mana seseorang dihadapkan pada satu peluang, tuntutan, dan sumber daya yang terkait dengan keinginan orang tersebut serta hasilnya dipandang tidak pasti dan penting", sedangkan menurut Rivai dan Mulyadi (2012), stres kerja merupakan kondisi yang disebabkan ketidakseimbangan antara kepribadian dengan karakteristik pekerjaan. Menurut Handoko (2008), stres kerja adalah suatu ketegangan yang berpengaruh terhadap emosi, kondisi, pikiran, dan akibatnya stres yang terlalu tinggi dapat mengancam kemampuan seorang dalam berhadapan dengan lingkungannya sehingga hal ini mengganggu pelaksanaan tugasnya.

Dari pendapat para ahli diatas maka diambil kesimpulan bahwa stres kerja adalah ketegangan atau kondisi yang didapat seseorang akibat dari tuntutan, pekerjaan yang didapatkan dan nantinya akan berpengaruh terhadap proses berpikir, emosi, dan kondisi, sehingga dapat mengganggu seseorang dalam melakukan pekerjaannya.)

Quick dalam Rivai dan Mulyadi (2012) membagi stres ke dalam 2 jenis, yaitu:

\section{a. Eustres}

Eustres adalah hasil respon terhadap stres yang bersifat positif, sehat, dan konstruktif bersifat membangun. Adalakanya karyawan memerlukan stres agar termotivasi untuk bekerja. Stres yang ada justru dapat diolah menjadi suatu semangat positif dalam mengatasi kejadian atau mencapai sesuatu.

\section{b. Distres}

Distres adalah hasil dari respon terhadap stres yang bersifat negatif, tidak sehat, dan destruktif bersifat merusak. Distres ada ketika individu tidak dapat mempertahankan level stres yang mereka alami. Stres inilah yang kemudian merusak kinerja seseorang. Distres terjadi ketika individu menyadari adanya masalah dalam situasi yang penting, namun dia tidak yakin dapat mengatasi masalah tersebut. Menurut Greenberg dan Baron dalam George (2015) work stress in organizations can result in negatif effects like decreased capacity to perform, reduced efficiency, and depression, and depression, yang berarti stres kerja dapat berpengaruh buruk seperti mengurangi efisiensi, mengurangi kapasitas pekerjaan yang dilakukan, dan depresi.

\section{Kinerja Karyawan}

Kinerja karyawan adalah kesediaan seseorang atau sekelompok orang untuk melakukan pekerjaan sesuai dengan tanggung jawab dan hasil yang telah diharapkan. Pengertian kinerja yaitu prestasi yang dicapai oleh karyawan sesuai dengan tanggung jawab, untuk mencapai tujuan perusahaan dengan tidak melanggar aturan, moral atau etika (Rivai, 2012). Pengertian kinerja yang dijelaskan oleh Mangkunegara (2012) merupakan hasil kerja dilihat dari kualitas dan kuantitasnya yang sanggup dikerjakan oleh karyawan sesuai dengan tanggung jawab. Kinerja diartikan oleh Ilyas (2005), yaitu hasil karya personil baik kualitas, maupun kuantitas yang memangku jabatan fungsional maupun structural.

Dari pendapat para ahli diatas, diambil kesimpulan bahwa kinerja karyawan adalah prestasi, hasil yang sanggup dikerjakan oleh seseorang sesuai dengan tanggungjawab dan pekerjaan yang diberikan oleh perusahaan kepada orang tersebut yang dapat dilihat dari kualitas kerja dan kualitas kerja.

Kinerja pegawai, menurut Dharma (2014), diukur dengan indikator kinerja sebagai berikut:

1. Kuantitas kerja, jumlah hasil kerja yang dilakukan oleh seorang karyawan.

2. Kualitas kerja, yang berarti kesesuaian hasil pekerjaan dengan standar yang dituntut ataupun rencana organisasi.

3. Ketepatan waktu, adalah kesesuaian waktu yang dibutuhkan dan diharapkan dalam pelaksanaan kerja. 
Sementara menurut Bangun (2012), indikator kinerja terdiri dari:

1. Kuantitas pekerjaan, yaitu jumlah pekerjaan yang dapat dilakukan dan dicapai individu atau kelompok yang menjadi standar.

2. Kualitas pekerjaan, syarat dan tuntutan yang dipenuhi karyawan dalam pekerjaannya.

3. Ketepatan waktu, yaitu kesesuaian antara pekerjaan dengan waktu yang ditentukan.

4. Kehadiran. Tingkat kehadiran karyawan dalam bekerja akan berhubungan dengan ketepatan waktu dalam menyelesaikan suatu pekerjaan.

5. Kemampuan kerjasama. Suatu pekerjaan kadang memerlukan karyawan untuk bisa bekerja sama dalam menuntaskan pekerjaan, maka dari itu kemampuannya bekerja sama dengan reka sekerja lainnya dapat menjadi tolak ukur.

\section{Hubungan Stres Kerja dan Kinerja}

Menurut Robbins (2013) stres tingkat rendah sampai sedang dapat meningkatkan kinerja. Pada tingkatan ini seseorang mengerjakan tugas lebih baik, intensif, dan cepat. Tapi jika terlalu tinggi stres akan mengakibatkan kinerja menjadi lebih rendah. Stres pada tingkat rendah justru berpengaruh negatif terhadap kinerja individu dan melemahkan sumber daya energinya. Stres dapat membantu, tetapi juga dapat menurunkan kinerja. Hal ini berarti stres memiliki potensi dalam mengganggu ataupun mendorong seseorang melakukan pekerjaan, tergantung besarnya tingkat stres tersebut. Apabila tidak adanya stres, seseorang tidak memiliki tantangan dalam bekerja, kinerja akan cenderung rendah. Sedangkan jika stres meningkat, kinerja cenderung naik, ini disebabkan stres membantu karyawan mengerahkan kemampuan dalam pemenuhan syarat dan kebuuthan pekerjaan. Apabila tingkat stres terlalu tinggi, kinerja mulai turun kembali karena mengganggu pelaksanaan pekerjaan. Karyawan mulai kehilangan kemampuannya dalam mengendalikan pekerjaan. Akibatnya prestasi kerja akan menurun. Hubungan ini diperkuat oleh penelitian terdahulu sebagai berikut.

Penelitian ini memiliki kerangka pemikiran sebagai berikut:

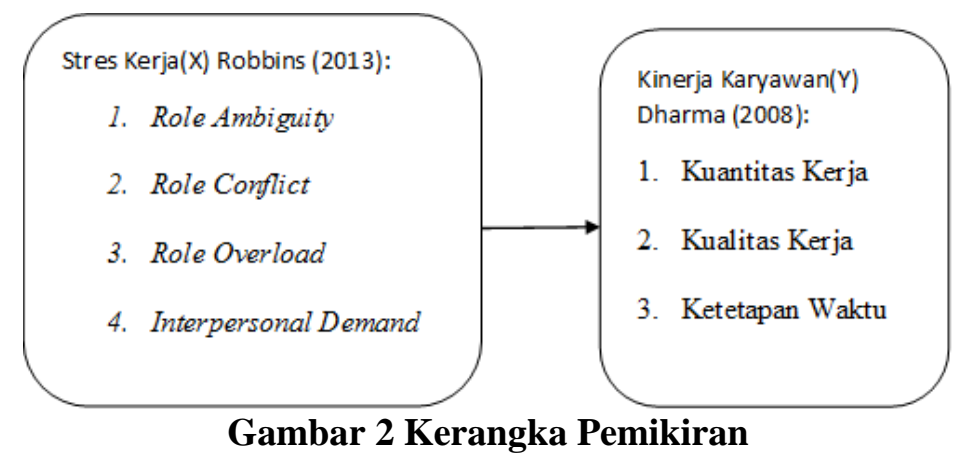

Berdasarkan fenomena yang telah dipaparkan, maka hipotesis untuk penelitian ini adalah:

H0: Tidak terdapat pengaruh yang signifikan work related stress terhadap kinerja karyawan.

Ha: Terdapat pengaruh yang signifikan work related stress terhadap kinerja karyawan.

\section{Metode Penelitian}

Penelitian ini dilakukan pada karyawan account executive PT. Agrodana Futures Bandung (Marketing Branch). Objek penelitian yang menjadi variabel bebas (independent variabel) dalam penelitian ini adalah stres kerja $(\mathrm{X})$, sedangkan variabel yang terikat (dependent variabel) dari penelitian ini adalah kinerja karyawan (Y). Penelitian ini menguji dampak work related stress terhadap kinerja karyawan account executive PT Agrodana Futures Bandung (Marketing Branch).

Pada penelitian ini, pengumpulan data menggunakan metode penelitian survei deskriptif. Metode survey yang dilakukan dalam penelitian ini terdiri dari observasi, wawancara, dan kuesioner. Penelitian ini menggunakan metode kuantitatif. Penelitian ini terdapat variabel independen dan dependen. Variabel tersebut dicari seberapa besar pengaruhnya dari variabel independen terhadap variabel deenden. (Sugiyono, 2013: 11). Dalam penelitian ini yang merupakan variabel independen adalah work related stress atau stres kerja. Sedangkan variabel dependennya adalah kinerja karyawan. 
Penelitian ini menggunakan sampel metode simple random sampling. Di dalam pengambilan sampel, subjek acak berada dalam populasi sehingga semua subjek dianggap sama, caranya dengan membagikan kuesioner kepada karyawan account executive PT Agrodana Futures Bandung (Marketing Branch). Cara menentukan sampel yaitu sebagai berikut:

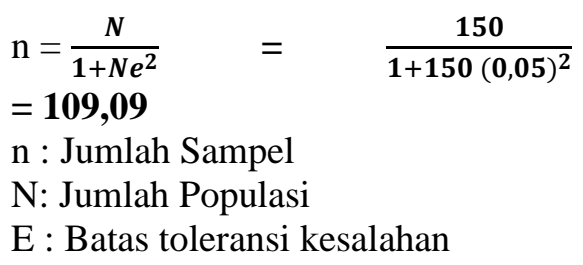

Dari rumus diatas didapatkan sampel yang akan diteliti yaitu sebesar 110 karyawan account executive. Penelitian ini menggunakan 4 kriteria yaitu sangat rendah, cukup rendah, cukup tinggi, sangat tinggi. Berikut ini adalah tabel kriteria kelas.

Tabel 3 Interval Rata-rata

\begin{tabular}{|c|c|}
\hline Skala & Kriteria \\
\hline $1,00-2,00$ & Sangat Rendah \\
\hline $2,10-3,00$ & Cukup Rendah \\
\hline $3,10-4,00$ & Cukup Tinggi \\
\hline $4,10-5,00$ & Sangat Tinggi \\
\hline
\end{tabular}

\section{Hasil dan Pembahasan}

Responden dalam penelitian ini yaitu sebanyak 110 orang, terdiri dari 48 laki-laki dan 62 wanita. Kelompok usia responden yang terbanyak adalah kelompok usia 20-30 tahun. Kelompok lama kerja yang terbanyak adalah kelompok lama bekerja $<3$ bulan. Pendidikan terakhir yang terbanyak adalah pendidikan terakhir Sarjana.

Uji validitas dilakukan untuk menunjukkan bahwa data yang dilaporkan sesuai dengan data yang sesungguhnya atau yang terjadi sesuai dengan objek penelitian. Menurut Sugiyono suatu data dikatakan valid apabila korelasi dari suatu variabel $\geq 0,3$. Uji validitas terhadap 24 instrumen pernyataan/pertanyaan tentang penentuan pandangan terhadap investasi dengan menggunakan SPSS versi 22 pada 110 responden dinyatakan valid dikarenakan $r$ hitung $\geq 0,1,576$. Variabel kinerja karyawan dikatakan valid karena $\mathrm{r}$ hitung $\geq 0,1576$.

Uji reliabilitas dilakukan untuk mengetahui sejauh mana tingkat keterpercayaan data yang diperoleh untuk diteliti. Menurut Noor (2014) jika nilai Alpha > 0,60 disebut reliabel. Skor hasil pengukuran untuk kedua variabel adalah 0,881 dan 0,843, masing-masing, sehingga dapat dipercaya dan terhindar dari kekeliruan pengukuran (measurement error).

\section{Uji Analisis Deskriptif}

Berdasarkan rumusan masalah maka variabel peneiltian dibedakan menjadi variabel bebas dan terikat untuk mengetahui besaran setiap variabelnya maka dilakukan uji analisis deskriptif. Berikut ini adalah hasil uji analisis deskriptif dari penelitian ini.

Berdasarkan hasil keseluruhan pada tabel 4 , dimensi variabel work related stress mempunyai nilai rata-rata 3,67 yang berarti termasuk ke dalam kategori cukup tinggi. Dimensi yang memiliki rata-rata paling tinggi adalah dimensi role ambiguity sebesar 3,77 dan terendah adalah role conflict dengan nilai 3,54 dimana keduanya termasuk dalam kategori cukup tinggi. Nilai standar deviasi pada variabel work related stress adalah 0,46026 yaitu sebesar $12,5 \%$ dari rata-rata, berada dibawah $20 \%$ yang menunjukkan bahwa jawaban responden memiliki tingkat variasi yang rendah. Jadi dapat disimpulkan bahwa work related stress yang terjadi pada karyawan account executive PT. Agrodana Futures Bandung adalah cukup tinggi. Pada variabel ini dimensi role conflict dengan nilai rata-rata terbesar 3,54 yang termasuk ke dalam kategori cukup tinggi, dan nilai rata-rata tertinggi adalah dimensi role ambiguity dengan nilai rata-rata 3,77.

\section{Tabel 4 Hasil Uji Analisis Deskriptif}




\begin{tabular}{|l|l|l|l|l|l|}
\hline & N & Min & Max & Mean & Std. Dev \\
\hline Role_Ambiguity & 110 & 2,00 & 5,00 & 3,77 &, 686 \\
\hline Role_Conflict & 110 & 2,50 & 5,00 & 3,54 &, 519 \\
\hline Role_Overload & 110 & 2,75 & 5,00 & 3,75 &, 522 \\
\hline Interpersonal_Demand & 110 & 2,67 & 5,00 & 3,74 &, 616 \\
\hline Work_Stress & $\mathbf{1 1 0}$ & $\mathbf{2 , 6 7}$ & $\mathbf{4 , 9 3}$ & $\mathbf{3 , 6 7}$ & $\mathbf{, 4 6 0}$ \\
\hline Valid N (listwise) & 110 & & & & \\
\hline
\end{tabular}

Berdasarkan hasil uji deskriptif, dimensi variabel kinerja mempunyai nilai rata-rata 3,60 yang berarti termasuk dalam kategori cukup tinggi. Dimensi yang memiliki nilai rata-rata paling tinggi adalah dimensi ketepatan waktu yang bernilai 3,69 dan terendah adalah kuantitas kerja dengan nilai 3,45 dimana keduanya memiliki kategori cukup tinggi. Nilai standar deviasi pada variabel kinerja adalah 0,45791 yaitu sebesar 12,6\% dari rata-rata, berada dibawah $20 \%$ yang menunjukkan bahwa jawaban responden memiliki tingkat variasi yang rendah. Jadi dapat disimpulkan bahwa kinerja karyawan account executive PT Agrodana Futures Bandung adalah tinggi.

Tabel 5 Hasil Uji Analisis Deskriptif

\begin{tabular}{|l|l|l|l|l|l|}
\hline & $\mathbf{N}$ & Min & Max & Mean & Std. Dev \\
\hline Kualitas_Kerja & 110 & 2,00 & 5,00 & 3,66 &, 526 \\
\hline Kuantitas_Kerja & 110 & 2,00 & 5,00 & 3,45 &, 588 \\
\hline Ketepatan_Waktu & 110 & 2,67 & 5,00 & 3,69 &, 476 \\
\hline Kinerja & $\mathbf{1 1 0}$ & $\mathbf{2 , 5 6}$ & $\mathbf{5 , 0 0}$ & $\mathbf{3 , 6 0}$ &, $\mathbf{4 5 7}$ \\
\hline Valid N (listwise) & 110 & & & & \\
\hline
\end{tabular}

Tabel 6 Hasil Uji Korelasi Sederhana

\begin{tabular}{|l|l|l|l|}
\hline \multicolumn{2}{|l|}{ Work_Related_Stress } & Work_Related_Stress & Kinerja_Karyawan \\
& $\begin{array}{l}\text { Pearson } \\
\text { Correlation }\end{array}$ & 1 &, $801^{* *}$ \\
\cline { 2 - 4 } & Sig. (2-tailed) & &, 000 \\
\cline { 2 - 4 } & $\mathrm{N}$ & 110 & 110 \\
\hline \multirow{5}{*}{ Kinerja_Karyawan } & $\begin{array}{l}\text { Pearson } \\
\text { Correlation }\end{array}$ &, $801^{* *}$ & 1 \\
\cline { 2 - 4 } & Sig. (2-tailed) &, 000 & 110 \\
\cline { 2 - 3 } & $\mathrm{N}$ & 110 & \\
\hline \multirow{2}{*}{$* *$. Correlation is significant at the 0.01 level (2-tailed). } & \\
\hline
\end{tabular}

Berdasarkan tabel 6, dapat dilihat bahwa nilai Pearson Correlation antara variabel work related stress dan kinerja adalah 0,801 yang termasuk ke dalam interval sangat kuat. Nilai signifikansi pada kedua variabel adalah 0,000 dimana nilai tersebut kurang dari 0,05 ini menunjukkan bahwa terdapat hubungan yang signifikan antara variabel work related stress dan kinerja karyawan. Jadi kesimpulannya, hubungan antara work related stress dan kinerja karyawan account executive PT Agrodana Futures Bandung adalah signifikan dan tinggi.

Uji regresi dilakukan untuk menjawab rumusan masalah ketiga, untuk mengetahui seberapa besar dampak work related stress terhadap kinerja karyawan. Pada tabel 7 , pada kolom B constant (a) memiliki nilai 6,120 , sedangkan nilai work related stress (b) adalah 0,478 sehingga persamaan regresinya dapat ditulis:

$\mathrm{Y}=\mathrm{a}+\mathrm{bX}$

$Y=6,120+0,478 X$

Persamaan tersebut berarti, apabila tanpa variabel work related stress, maka variabel kinerja hanya mencapai nilai 16,043. Koefisien nilai (a) bernilai positif, ini menunjukkan jika terjadi penambahan satu X maka akan meningkatkan Y sebesar 0,478. Jadi dapat disimpulkan bahwa setiap naik satu satuan nilai work related stress maka kinerja karyawan akan bertambah. 
Tabel 7 Hasil Uji Regresi

\begin{tabular}{|c|c|c|c|c|c|}
\hline \multirow[t]{2}{*}{ Model } & \multicolumn{2}{|c|}{ Unstandardized Coefficients } & Standardized Coefficients & $\mathrm{t}$ & Sig. \\
\hline & B & Std. Error & Beta & & \\
\hline \begin{tabular}{l|l}
1 & (Constant) \\
\end{tabular} & 6,120 & 1,908 & & 3,207 & 002 \\
\hline $\begin{array}{l}\text { Work_Related_ } \\
\text { Stress }\end{array}$ & ,478 &, 034 & 801 & 13,908 & 000 \\
\hline
\end{tabular}

\section{Uji Hipotesis}

Uji hipotesis yang digunakan pada penelitian ini terdapat dua metode, yaitu menggunakan uji t dan uji F. Berdasarkan hasil tabel 8, dapat dilihat bahwa signifikansi memiliki nilai 0,000. Nilai tersebut lebih kecil dari nilai probabilitasnya yaitu sebesar $5 \%$ atau 0,05 . Nilai $\mathrm{F}$ hitung (F0) yang ada bernilai 193,433, dengan menggunakan tingkat signifikansi 0,05 dan df1: $(\mathrm{k}-1)=2-1=1$ dan df $2:(\mathrm{n}-\mathrm{k})=110-2$ $=108$ maka diperoleh F 30acto $(\mathrm{F} 1)(1 ; 108)$ sebesar 3,93. Hasil tersebut dapat dihitung dengan menggunakan peranti lunak Microsoft Excel dengan rumus sebagai berikut:

$=\operatorname{FINV}(0,05 ; 1 ; 108)$

$=3,93$

Berdasarkan hasil perhitungan tersebut, artinya bahwa nilai F0 > F1 yaitu 193,433>3,93. Jika F0 > F1, dengan taraf signifikansi 5\% maka dapat diartikan bahwa H0 ditolak dan Ha diterima. Hal tersebut menunjukkan bahwa work related stress berpengaruh secara signifikan terhadap kinerja karyawan account executive di PT. Agrodana Futures Bandung.

Tabel 8 Hasil Uji Statistik F

\begin{tabular}{|c|c|c|c|c|c|}
\hline Model & Sum of Squares & $\mathrm{df}$ & $\begin{array}{l}\text { Mean } \\
\text { Square }\end{array}$ & $\mathrm{F}$ & Sig. \\
\hline \begin{tabular}{l|l}
1 & Regression
\end{tabular} & 1187,982 & 1 & 1187,982 & 193,433 &, $000^{\mathrm{b}}$ \\
\hline Residual & 663,291 & 108 & 6,142 & & \\
\hline Total & 1851,273 & 109 & & & \\
\hline \multicolumn{6}{|c|}{ a. Dependent Variabel: Kinerja_Karyawan } \\
\hline \multicolumn{6}{|c|}{ b. Predictors: (Constant), Work_Related_Stress } \\
\hline
\end{tabular}

Tabel 9 Hasil Uji Statistik t

\begin{tabular}{|l|l|l|l|l|l|l|}
\hline \multirow{2}{*}{ Model } & \multicolumn{2}{|l|}{$\begin{array}{l}\text { Unstandardized } \\
\text { Coefficients }\end{array}$} & $\begin{array}{l}\text { Standardized } \\
\text { Coefficients }\end{array}$ & t & \multirow{2}{*}{ Sig. } \\
\cline { 2 - 5 } \multicolumn{2}{|l|}{1} & B & Std. Error & Beta & & \\
\hline \multirow{2}{*}{1} & 6,120 & 1,908 & & 3,207 &, 002 \\
\cline { 2 - 4 } & Work_Related_Stress &, 478 &, 034 &, 801 & 13,908 &, 000 \\
\hline \multicolumn{2}{|l|}{ a. Dependent Variabel: Kinerja_Karyawan } \\
\hline
\end{tabular}

Dari tabel 9 dapat dilihat bahwa nilai signifikansi work related stress adalah 0,000. Nilai tersebut lebih kecil dari nilai probabilitasnya sebesar 0,05 . Nilai t hitung yang ada bernilai 13,908 dengan menggunakan tingkat signifikansi 0,05 , df $1:(\mathrm{k}-1)=2-1=1$ dan df $2(\mathrm{n}-\mathrm{k})=110-2=108$, diperoleh $\mathrm{t}$ tabel $(1 ; 108)$ sebesar 1,98217 . Hasil tersebut dapat dihitung dengan menggunakan peranti lunak Microsoft excel dengan cara sebagai berikut:

$$
\begin{aligned}
& =\operatorname{TINV}(0,05 ; 108) \\
& =1,98217
\end{aligned}
$$

Berdasarkan hasil perhitungan diatas, maka dapat dinyatakan bahwa t hitung $>\mathrm{t}$ tabel yaitu 13,908 $>1,98217$. Jika t hitung lebih besar dari t tabel dengan taraf signifikansi 5\%, diartikan bahwa H0 ditolak dan Ha diterima. Hal ini menunjukkan bahwa work related stress berpengaruh secara signifikan terhadap kinerja karyawan account executive PT Agrodana Futures Bandung.

Tabel 10 Koefisien Determinasi

\begin{tabular}{|l|l|l|l|l|}
\hline Model & R & R Square & Adjusted R Square & Std. Error of the Estimate \\
\hline
\end{tabular}




\begin{tabular}{|l|l|l|l|l|}
\hline 1 &, $801^{\mathrm{a}}$ &, 642 &, 638 & 2,47822 \\
\hline \multicolumn{2}{|l|}{ a. Predictors: (Constant), Work_Related_Stress } \\
\hline
\end{tabular}

Koefisien determinasi digunakan untuk melihat kontribusi pengaruh yang diberikan variabel bebas yaitu work related stress terhadap variabel terikat yaitu kinerja karyawan. Koefisien determinasi juga digunakan untuk menjawab rumusan masalah ketiga yaitu pengaruh work related stress terhadap kinerja karyawan account executive PT. Agrodana Futures Bandung. Dari tabel 10 diperoleh R Square atau angka korelasi kuadrat adalah 0,642. Angka tersebut disebut sebagai koefisien determinasi. Jadi, dapat disimpulkan koefisien determinasi pada penelitian ini adalah 0,642 atau 64,2\%. Besaran ini menunjukkan work related stress berpengaruh sebesar $64,2 \%$ terhadap kinerja karyawan. Sementara sisanya yaitu $35,8 \%$ dipengaruhi oleh faktor-faktor lain yang tidak dijelaskan dalam penelitian ini.

\section{Kesimpulan dan Saran}

Work related stress/stres kerja yang terjadi pada karyawan account executive PT Agrodana Futures Bandung adalah cukup tinggi. Hal ini dikarenakan, yaitu dimensi role ambiguity, role conflict, role overload, interpersonal demand adalah cukup tinggi. Dimensi role ambiguity memiliki nilai rata-rata tertinggi, sedangkan dimensi yang memiliki nilai rata-rata terendah adalah dimensi role conflict yaitu sebesar, dimana kedua dimensi tersebut termasuk dalam kategori cukup tinggi. Indikator dengan mean tertinggi adalah indikator pada dimensi role conflict yaitu pernyataan "merasa tidak jelas dalam memperoleh kenaikan jabatan" yang berada pada kategori cukup tinggi, dan indikator terendah berada pada dimensi role conflict yaitu pernyataan "merasa tidak layak untuk bekerja" dengan nilai yang termasuk ke dalam kategori cukup. Menurut hasil observasi PT Agrodana Futures Bandung merupakan kantor marketing branch yang melakukan pemasaran mengenai komoditi. Dari pernyataan pertama diketahui bahwa ketidakjelasan tanggung jawab adalah cukup tinggi. Ini dikarenakan Tugas dari account executive adalah mencari investor. Job deskripsi yang hanya mengandalkan kreatifitas karyawannya untuk mendapatkan investor akan membingungkan karyawan mengenai tanggung jawab yang diberikan kepadanya. Tidak semua manajer tim memberikan job desk kepada setiap karyawannya secara rinci, sehingga karyawan yang baru tidak mengetahui apa yang harus dikerjakan dan terkadang manajer tim terlalu mengandalkan kreatifitas karyawannya dalam mendapatkan investor.

Kinerja karyawan account executive PT Agrodana Futures Bandung adalah cukup tinggi. Dimensi yang memiliki nilai rata-rata tertinggi adalah dimensi ketepatan waktu dan terendah adalah dimensi kuantitas kerja, dimana keduanya termasuk dalam kategori cukup tinggi. Indikator yang tertinggi yaitu pada dimensi kuantitas kerja dengan pernyataan "memenuhi jumlah tuntutan kerja yang diharapkan" berada pada kategori cukup tinggi dan terendah adalah pernyataan "memenuhi jumlah tuntutan kerja yang diharapkan" yang berada pada kategori cukup tinggi. Dalam waktu 3 bulan karyawan account executive dituntut untuk mendapatkan investor untuk menginvestasikan dananya sebesar 300juta rupiah, berarti hanya sebagian karyawan yang dapat mencapai target dana investor.

Dampak work related stress terhadap kinerja karyawan account executive termasuk dalam kategori cukup tinggi, ini ditunjukkan dengan pengaruh positif sebesar $64,2 \%$ dan sisanya $35,8 \%$ dipengaruhi oleh faktor-faktor lain.

Meskipun dari hasil penelitian kinerja karyawan account executive PT. Agrodana Futures Bandung termasuk tinggi, namun PT. Agrodana Future Bandung harus selalu melakukan pengawasan terhadap karyawannya. Oleh karena itu, ada beberapa saran yang berhubungan dengan penelitian yang dilakukan, antara lain sebagai berikut:

1. Work related stress pada karyawan account executive PT Agrodana Futures Bandung adalah cukup tinggi. Tapi dalam batasan stres tertentu stres kerja dapat berpengaruh negatif terhadap karyawan. Maka dari itu diperlukan pengelolaan stres agar didapatkan kinerja yang optimal serta diperlukan penanggulangan stres kerja ketika stres kerja sudah terlalu tinggi, agar kinerja karyawan yang menurun akan kembali meningkat. Hal-hal dalam mengelola stress bisa dilakukan seperti memperkaya desain pekerjaan (seperti tanggung jawab, pengakuan, dan kesempatan untuk pencapaian, peningkatan, dan pertumbuhan), mengurangi konflik mengklarifikasi peran organisasional seperti memperjelas deskripsi pekerjaan, menciptkan iklim organisasional yang mendukung. 
2. Kuantitas pekerjaan merupakan dimensi yang memiliki mean terkecil. Ini disebabkan banyak karyawan tidak mencapai target dana investor. Dalam membantu karyawan agar mencapai targetnya. Perusahaan dapat mempromosikan bisnis komoditi kepada masyarakat luas. Karena bisnis komoditi seperti ini jarang diketahui oleh masyarakat luas. Terdapat banyak cara dalam melakukan pemasaran, tapi PT. Agrodana Futures Bandung belum melakukan semua cara dalam pemasaran. Cara yang sudah dilakukan dan sering dilakukan adalah penjualan secara personal, pemasaran langsung, dan promosi penjualan. Sementara yang jarang digunakan adalah iklan, publisistas, dan lain-lain.

3. Perusahaan dapat menampung pendapat-pendapat karyawannya agar mengetahui masalah yang terjadi pada karyawan, sehingga dengan membantu karyawan dengan keluhannya diharapkan dapat meningkatkan kinerja mereka.

\section{Daftar Pustaka}

Bangun, W. (2012). Manajemen Sumber Daya Manusia. Jakarta: Erlangga.

Baron \& Byrne. (2005). Sosial Psychology (10th ed). Pearson Education, Inc.

Dharma, A. (2014). Manajemen Supervisi. Jakarta: Raja Grafindo Persada.

Gani, I. \& Amalia, S. (2015). Alat Analisis Data; Aplikasi Statistik untuk Penelitian Bidang Ekonomi dan Sosial. Yogyakarta: Andi Offset.

George, E. (2013). Job related stress and job satisfaction: a comparative study among bank employees. Department of Management Studies. Kerala: Adi Shankara Institute of Engineering and Technology (ASIET).

Ghozali, I. (2013). Aplikasi Analisis Multivariat dengan Program IBM SPSS. 21. Edisi 7. Semarang: Penerbit Universitas Diponegoro.

Hasibuan, M. (2012). Manajemen Sumber Daya Manusia. Edisi Revisi. Jakarta: Bumi Aksara.

Joiner, T. A. (2000). The Influence Of National Culture And Organizational Culture Alignment On Job Stress And Performance: Evidence From Greece. Bundoara: Latrobe University.

Mangkunegara, A. P. (2012). Manajemen Sumber Daya Manusia Perusahaan. Bandung: PT. Remaja Rosolakarya Offset.

Ornelas, S. (2003). New Developments in Managing Job Related Stress. California: Department of Management, College of Business and Economics.

Rivai, V. \& Mulyadi, D. (2012). Kepemimpinan dan Perilaku Organisasi Edisi Ketiga. Jakarta: Raja Grafindo Persada.

Rivai, V., Fawzi, D. A., \& Basri, M. (2012). Performance Appraisal, sistem yang tepat untuk menilai kinerja karyawan dan meningkatkan daya saing perusahaan. Jakarta: Raja Grafindo Persada.

Robbins, S. P., \& Judge T. A. (2008). Perilaku Organisasi. Jakarta: Salemba Empat.

Robbins, S. P. (2013). Perilaku Organisasi. Jakarta: PT. Indeks Kelompok GRAMEDIA.

Siswanto, V. A. (2015). Belajar Sendiri SPSS 22. Yogyakarta: Andi Offset.

Sugiyono. (2011). Metode Penelitian Kombinasi. Bandung: Alfabeta

Sugiyono. (2013). Metode Penelitian Kuantitatif Kualitatif dan Kombinasi (Mixed Methods). Bandung: Alfabeta.

Sugiyono. (2014). Metode Penelitian Bisnis. Cetakan ke 18. Bandung: Alfabeta.

Sunyoto, D. (2013). Manajemen Sumber Daya Manusia. Yogyakarta: Caps.

Tho, N. D. (2017). Marketers' Human Capital Resources and Job Performance. University of Economics Ho Chi Minh City, Ho Chi Minh City, Vietnam and Western Sydney University, New South Wales, Australia.

\section{*Email korespondensi:}

Rizky Praditiya Herdiana

rizkypraditiya10@gmail.com 